Wheeler encamped on the glacier below the north col.

On the 24th they ascended the north col, connecting Everest with the north peak, to 23,000 ft., finding the northeast arête quite possible, but they were driven back by a furious northwesterly gale, lasting four days, with intense cold, and making all climbing impossible.

All the party are in good health. The reconaissance of Mount Everest is now completed.

The Times writes:

The expedition started from Darjeeling on May 18 and 19, and, taking its way through the switchback mountains of Sikkim, entered Tibet and then made westward to Tingri Dzong-north-northwest of Everest, which place was made the base for the exploration of the north and northwestern faces of the mountain. The utmost care had been taken in the fitting out of the expedition, but transport difficulties soon developed, for the mules supplied by the Indian Government broke down completely. Fortunately, Colonel Howard Bury was able to supply this deficiency locally.

The work of exploring the northwest approaches to Everest began on June 23, and on July 3 Messrs. Mallory and Bullock succeeding in climbing a peak over 23,000 ft. high. But means of ascent of Everest itself on this side proved utterly lacking-terrible precipices, descending 10,000 ft. on to a huge glacier, blocked the way. Even supposing that the rock summits at $20,000 \mathrm{ft}$. were gained-which seemed just possible-hard rockclimbing for the remaining $4,000 \mathrm{ft}$. was out of the question at that altitude.

As the north and west approaches had proved impracticable, camp was moved up Kharta at the end of July, and August devoted to reconnoitering the east side of the mountain. Here, again, disappointment awaited the climbers, for, as on the north and northwest, the eastern approaches were found to be guarded by huge precipices.

As a last resort the climbers then determined to follow up the Kharta-Tsangpo, a glacier stream, to its source, and it is in this direction that success has at length been obtained. A reconaissance early in August had shown the climbers a hitherto unknown valley which seemed to offer a practical route, and they reached a col nearly $23,000 \mathrm{ft}$. up looking on to the north ridge of Everest. The weather, however, had broken, and the climbers had to return to Kharta for a rest. They left Kharta again on August 31, and the telegram received to-day from Colonel Howard Bury tells of the happy ending to their endeavours.

Apart from this discovery of a way up the mountain, over 9,000 square miles of new territory have been surveyed.

\section{THE LABORATORY OF THE MIAMI AQUARIUM ASSOCIATION}

Students of marine life and especially those interested in fishes will be gratified to know of the establishment of a seaside laboratory by the Miami Aquarium Association at Miami Beach, Florida. The laboratory occupies the second floor in the south wing of the aquarium building and has accommodations for about ten investigators. It is provided with running fresh and salt water, with the usual laboratory outfit, and with reagent and photographic rooms. Materials for study are abundantly supplied from the large stock of the aquarium and from the neighboring waters. The aquarium runs a fleet of collecting boats including gasoline launches and three sea-going vessels: the Allisoni, moved by sail and gasoline, provided with live wells, and adapted to cruises of several days' length; L'A pache, a seventy-foot cruiser; and the Sea Horse, an eighty-five-foot, highpower cruising yacht just put into commission. In this way collecting trips may be made to the shoals in Biscayne Bay, the reefs in the open ocean, the Gulf Stream three miles distant, and to the Florida Keys and the Bahamas.

During a sojourn at the laboratory from the latter part of last May till the middle of July a great variety of interesting forms were met with. Physalia, the Portuguese man-of-war, with its symbiotic fish Nomeus, was abundant in the shore waters. During the latter part of June it was actively reproducing. At the same time the large rhizostomous jelly-fish Stomolophus was to be seen in great numbers off the coast. On the bank in Biscayne Bay the spiny sea-urchin Diadema and the giant conch Strombus were common. Spiny lobsters were always obtainable in great numbers. During July the eggs of the loggerhead turtle were hatching and sets of these were brought into the laboratory and studied there. But above all the region is immensely rich in the great variety of its highly colored, tropical fishes. 
These include the various kinds of angel-fishes, parrot-fishes, snappers, trunk-fishes, morays, barracudas, sea-horses, etc., and are most beautifully exhibited in the tanks of the aquarium. But much remains to be done in ascertaining what is available in the local fauna, and the director of the aquarium has already taken steps to carry out a preliminary biological survey of the region about Miami.

The aquarium is situated on the bay side of Miami Beach at the east end of the new causeway connecting the beach with the city of Miami. A line of electric cars crosses the causeway and makes the run in either direction in about twenty minutes. Hence a person working at the laboratory may reside either in Miami, the fourth largest city in Florida, or at Miami Beach, where sleeping apartments and bungalows may be had and where there are ample restaurant accommodations. Those who want particular information about the laboratory should apply to the director, Mr. L. L. Mowbray, Miami Aquarium, Miami Beach, Florida.

\section{HARVARD UNIVERSITY}

\section{G. H. PARKeR}

\section{THE TORONTO MEETING OF THE AMERICAN} SOCIETY OF ZOOLOGISTS

ThE executive committee of the American Society of Zoologists has decided to present at the meeting of the society at Toronto, Canada, December 28-30, 1921, a symposium program on the general subject of "Orthogenesis," broadly interpreted, the object being to bring into the discussion as many of the newer aspects from the varied fields of the natural and physical sciences as may be feasible. The speakers the committee have invited to address the society and the subjects of each speaker are as follows; several are still in the tentative stage, as indicated:

Professor L. J. Henderson, Harvard University, "Orthogenesis from the standpoint of the biochemist;" speaker to suggest an opener for the discussion. The speaker who has been invited is at present abroad.

Professor C. B. Lipman, University of California, "Orthogenesis in bacteria;", speaker to suggest an opener for the discussion.
Professor M. F. Guyer, University of Wisconsin, "Orthogenesis in serological reactions."

Professor Wm. Bateson, of England, discussion by Dr. O. C. Riddle, Cold Spring Harbor, Long Island, New York. Title not yet received.

Professor W. M. Wheeler, Harvard University, "Orthogenesis in ants;" discussion by Professor H. C. Crampton, Barnard College, New York City.

Professor H. F. Osborn, Columbia University, New York City, "Orthogenesis as observed from paleontological evidence beginning in the year 1889 ; ' discussion by Dr. J. C. Merriam, Carnegie Institution.

\section{Charles A. Kofoid,}

$$
\text { President }
$$

\section{SCIENTIFIC NOTES AND NEWS}

THE autumn meeting of the National Academy of Sciences will be held at the University of Chicago on November 14 and 15.

THE thirty-ninth stated meeting of the American Ornithologists' Union will convene in Philadelphia, at the Academy of Natural Sciences, from November 8 to 10 .

The Berzelius medal has been conferred on Professor E. Abderhalden, director of the physiological institute of the University of Halle, for his research on the defensive ferments and in other lines of biologic chemistry.

Mr. A. Crommelin, assistant astronomer of the Royal Observatory at Greenwich, has been awarded the Ponthecoulant Prize of the Paris Academy of Sciences in recognition of his general astronomical work.

President Harding has appointed Dr. John Glover South, of Frankfort, former president of the Kentucky State Medical Association, as minister to Panama.

JAMES A. CRAWFORD left his position with the Buffalo Botanic Gardens on October 1 to accept an appointment as assistant curator at the New York Botanical Garden.

George M. Rommer, now chief of the division of animal husbandry of the Bureau of Animal Industry, United States Department of Agriculture, became editor-in-chief of the publications of the American International Publishers of New York, beginning on November 1. These include The Field Illustrated; 